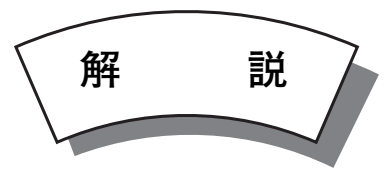

\title{
ボロンドープによるダイヤモンドの電気化学的特性の向上とその応用
}

\section{Electrochemical Property of Diamond Enhanced with Boron Doping, and its Application}

\author{
吉田 茂* · 小林 豊* • 中島 猛* \\ Shigeru YOSHIDA, Yutaka KOBAYASHI and Takeru NAKASHIMA
}

Key Words: Diamond. Electrochemistry. Chemical Vapor Deposition. Wastewater Treatment. Metal Recycling.

\section{1. 緒 言}

ダイヤモンドは物質中最高の硬度・熱伝導性を有し、ま た化学的安定性にも優れた物質である。その優れた性質を 利用し、研削・切削工具 (高硬度) や半導体レーザー用ヒー トシンク材料（高熱伝導性）など工業的に様々な用途に使 用されている。このようなダイヤモンド固有の特性に加え、 ボロンをドーピングすることでダイヤモンドは $\mathrm{p}$ 型半導体 となり、導電性が付与される。

ボロンドープ導電性ダイヤモンド (BDD：Boron Doped Diamond) の応用研究は、CVD 法 (Chemical Vapor Deposition：化学気相合成法)によるダイヤモンド合成技術 が普及した 1980 年代から急速に進んだ。BDDの応用は、 電解反応の電極として用いる電気化学的応用と、パワーデ バイスなどの半導体素子への応用に大別される。当初は半 導体の開発が先行していたが、 $\mathrm{n}$ 型のドーピングおよび低 欠陥エピタキシャル成長の技術課題が克服できず難航して いる。これに対し、電気化学的応用では、多結晶薄膜で十 分であり、結晶成長技術のハードルは半導体応用に比べ低 い。今世紀に入り、BDD 電極に用いた新しい電解反応の発 見が相次ぎ、実用化に向けた開発が急速に進展した ${ }^{1)}$ 。

BDD 電極の主な特徴として次の 3 つがある、

(1)広い電位空 (酸素発生過電圧と水素発生過電圧が高い)

これにより陽極・陰極どちらに用いても他の電極材料で は得られない特異な酸化・還元反応が可能。

(2)物理的・化学的に安定

ダイヤモンド自体が高硬度・高耐食性物質のため、污れ が激しい環境や、強酸・強アルカリ・有機溶媒中であっ ても長期間安定して使用可能。

(3)小さなバックグラウンド電流

シグナル / バックグランド比が大きいため電気化学分析 における高感度センサとして使用可能。

本稿では、用途に適した BDDの製造方法、および電気 化学的特性を利用した廃水処理（脱色処理、窒素性污染物

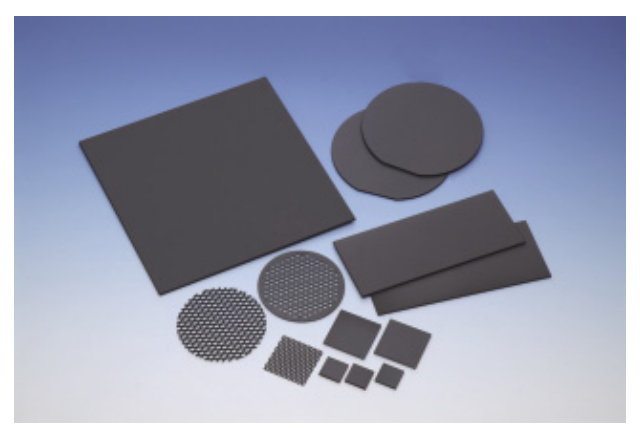

Fig. 1 BDD electrode.

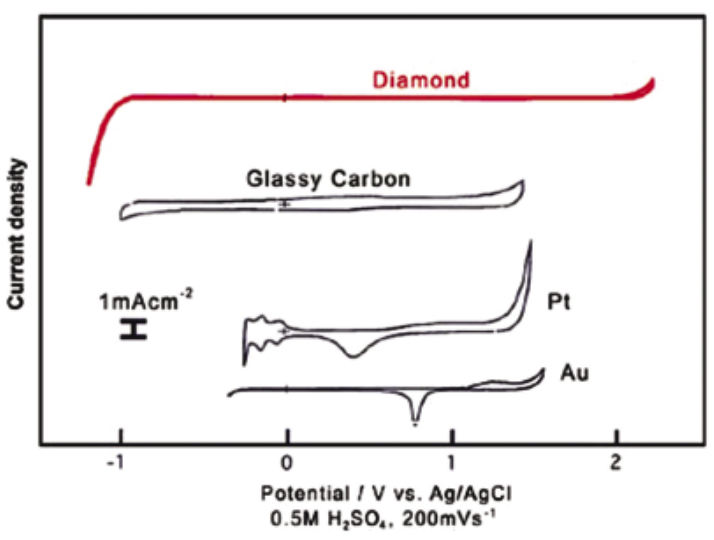

Fig. 2 Cyclic Voltamogram (CV) of various electrode materials. (Reprinted from Ref. [2] by courtesy of Prof. Einaga.)

質の処理）および銅のリサイクルを例に取り、BDD 電極の 特徴を報告する。

\section{BDD 電極の特性と製造条件の関係}

BDD 電極の用途は、センサ、廃水処理等の多岐に渡る。 特に重要となる BDD 電極の特性は、これらの用途で異なる。

*住友電工ハードメタル株式会社（＝ 664-0016 兵庫県伊丹市昆陽北 1-1-1）

Sumitomo Electric Hardmetal Corp (1-1-1, Koyakita, Itami, Hyogo 664-0016 Japan) 
例えば、分析などで用いられるセンサ用途では、高い酸素 発生過電圧、小さなバックグラウンド電流が重要である。 一方、工業的な廃水処理や機能性薬液生成などでは、高い 耐久性や高い導電性が重要視される場合が多い。

$\mathrm{BDD}$ 電極の特性は、金属などの電極材料とは異なり、 BDD を合成する時のパラメータでコントロールが可能であ る。つまり、用途に合わせて合成パラメータを選択すれば 良い。合成パラメータによる特性の変化を以下に示す。

熱フィラメント CVD 装置 (Fig. 3) を用いて、Table 1 に 示す条件で BDD を合成した。このとき、原料ガス中のメ タン濃度と、導電性を与えるドーパントであるボロンの濃

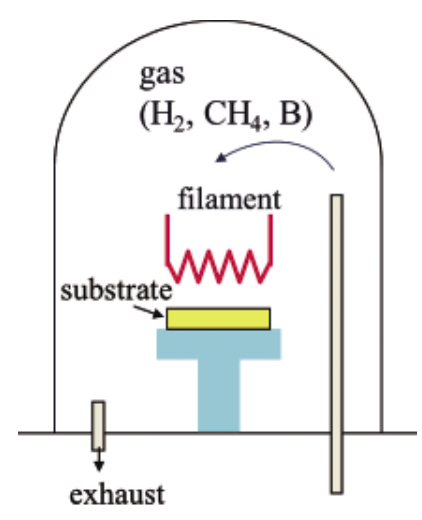

Fig. 3 Hot-filament CVD reactor.
度を Table 1 に示す組み合わせを用い 3 種類の試料（No.1， No.2, No.3）を作製した。

合成した BDD の SEM 観察像・膜厚・電気抵抗率などを Fig. 4 に示す。合成時のメタン濃度が高いNo.1, 2 はダイ ヤモンドの成長速度が大きいため、膜厚が大きい。更に、 No.1 においては、原料ガス中のボロンの濃度も大きく導電 性も高い。

各試料の酸素発生過電圧側の CV を Fig. 4 に示す。各試 料の $\mathrm{CV}$ の電流密度が $1 \mathrm{~mA} / \mathrm{cm}^{2}, 2 \mathrm{~mA} / \mathrm{cm}^{2}, 10 \mathrm{~mA} / \mathrm{cm}^{2}$ とな る電位を抽出し、Fig. 5 にプロットした。その結果、No.3 $>$ No.2 > No.1 に順に電位が高くなる傾向がみられた。

No.1, 2 の CV を見ると、一般的な BDD 電極の酸素発生 過電圧 $(2 \mathrm{~V})$ より低い $1.7 \mathrm{~V}$ 付近にピークがある（Fig. 4 太 矢印部)。一般に原料ガス中の炭素濃度が高い条件でダイヤ

Table 1 Synthesis conditions of BDD.

\begin{tabular}{|c|c|c|c|}
\hline \multicolumn{2}{|c|}{ Substrate } & \multicolumn{2}{|c|}{ P-type Si } \\
\hline \multicolumn{2}{|c|}{ Filament temperature } & \multicolumn{2}{|c|}{$2000-2050{ }^{\circ} \mathrm{C}$} \\
\hline \multicolumn{2}{|c|}{ Substrate temperature } & \multicolumn{2}{|c|}{$800-850{ }^{\circ} \mathrm{C}$} \\
\hline \multicolumn{2}{|c|}{ Pressure in reactor } & \multicolumn{2}{|c|}{$4 \mathrm{kPa}$} \\
\hline \multicolumn{2}{|c|}{ Synthesis time } & \multicolumn{2}{|c|}{10 hours } \\
\hline & & $\mathrm{CH}_{4} / \mathrm{H}_{2}$ & $\mathrm{~B} / \mathrm{C}$ \\
\hline \multirow{3}{*}{$\begin{array}{c}\text { Composition ratio } \\
\text { of source gases }\end{array}$} & Sample No.1 & $3 \%$ & $3000 \mathrm{ppm}$ \\
\hline & Sample No.2 & $3 \%$ & $300 \mathrm{ppm}$ \\
\hline & Sample No. 3 & $1 \%$ & $300 \mathrm{ppm}$ \\
\hline
\end{tabular}

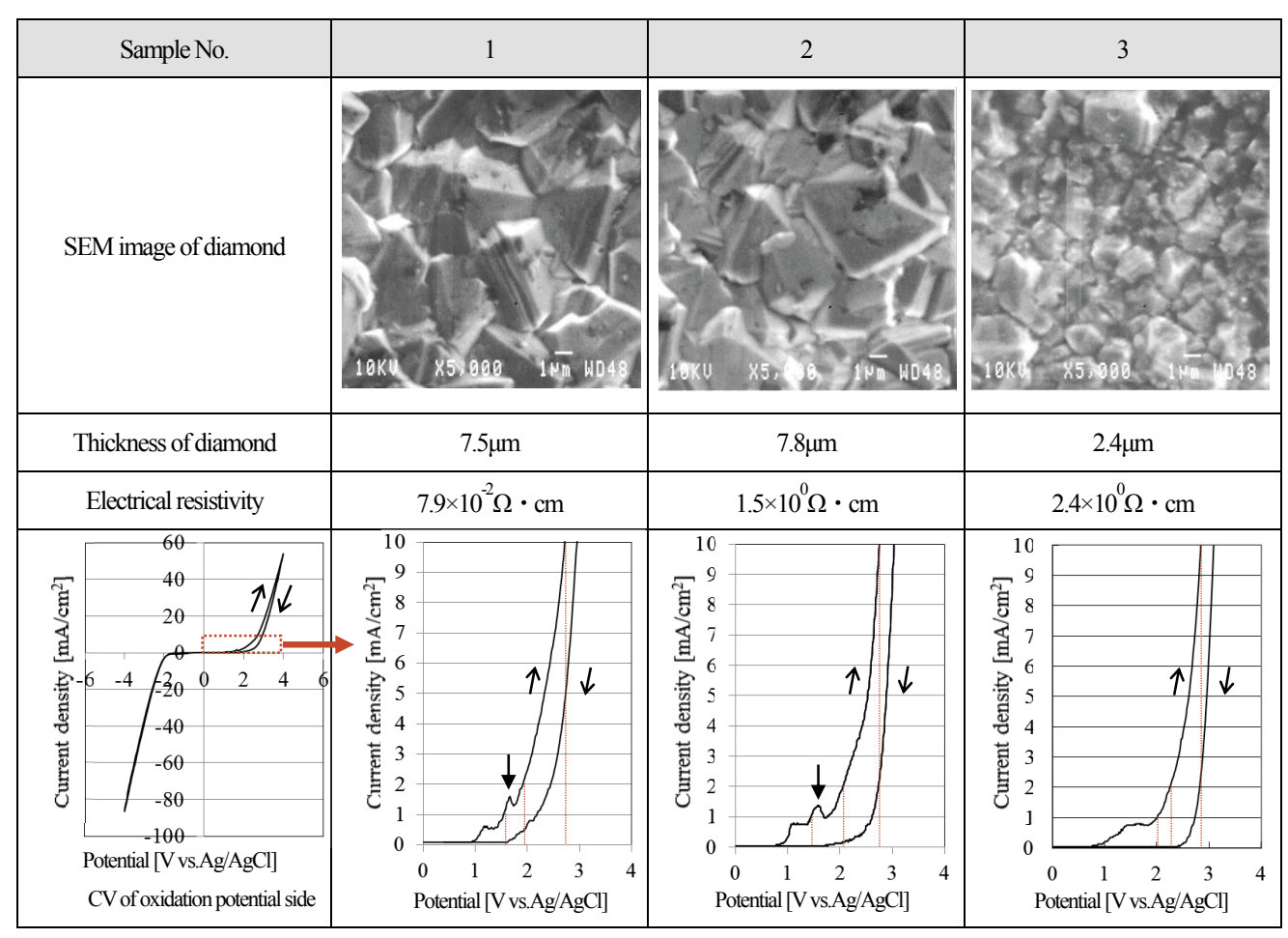

Fig. 4 Properties of synthesized BDD. 


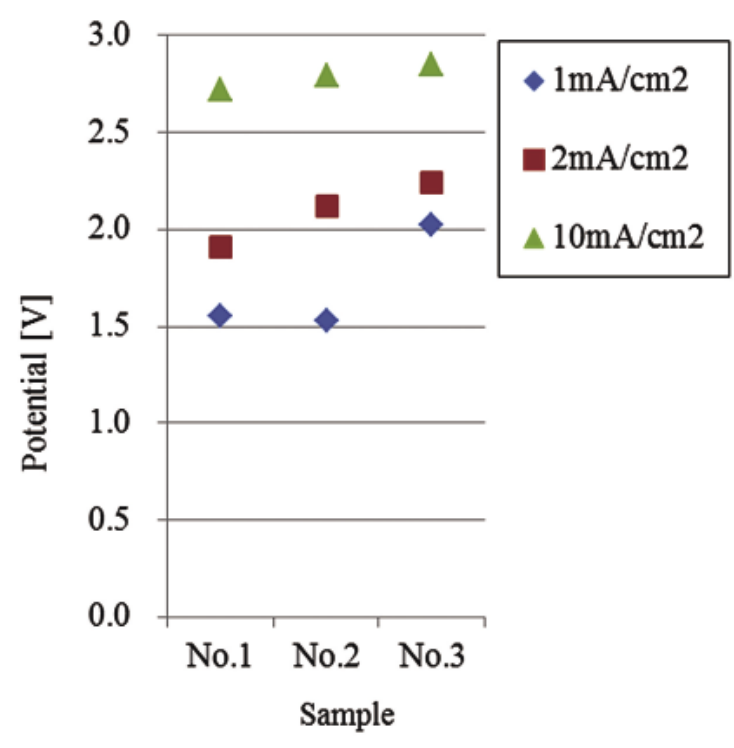

Fig. 5 Electrode potential of samples at constant current.

モンド合成した場合、ダイヤモンドの結晶中に $\mathrm{SP}^{2}$ 結合が 増えることが判っており、このピークは $\mathrm{SP}^{2}$ 結合によるも のである。また、ボロン濃度が増えると酸素発生過電圧が 低くなることが報告されており ${ }^{3)} 、 今$ 回のNo.1, 2 を比較し た場合も同様に、ボロン濃度が高いNo.1の方が低い傾向に ある。一方、メタン濃度もボロン濃度も小さいNo.3では肩 が見られる程度である。

以上のことから BDD の合成条件と BDD 電極の特性が確 認できた。耐久性（厚いダイヤモンド膜）・高い導電性が必 要な場合は、No.1のように高炭素濃度、高ボロン濃度で合 成し、高い酸素発生過電圧や、小さなバックグラウンド電 流が必要な場合は、No.3のように低炭素濃度、低ボロン濃 度で合成するのが良いことがわかる。

\section{BDD の電気化学的特性の応用}

3.1 廃水処理

BDD 電極の高い酸素発生過電圧・水素発生過電圧を利用 した廃水の浄化に関する研究が多数報告されている。ここ では、脱色処理及び窒素系污染物質の処理を中心に紹介す る。

\section{1) 脱色処理}

染色工場からの染色廃水や、牧場からの畜産廃水などの 着色廃水は、水辺の景観を損放る要因となるため、脱色処 理されることが望まれる。しかし、従来の廃水処理で用い られている、生物学的手法である活性污泥法や、物理化学 的手法である凝集沈殿法では、色素成分の除去が不十分で あり、着色された（色素成分が残留した）状態で自然界に 放出されているのが実情である。

近年、脱色処理法として電解酸化法が注目されてい

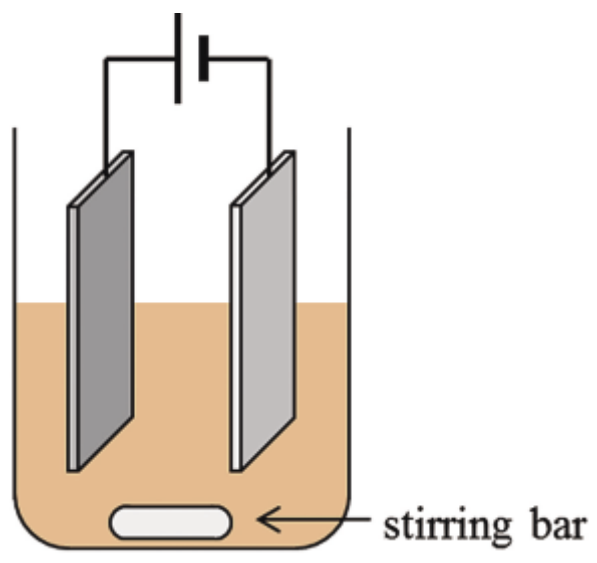

Fig. 6 Electrolytic treatment system for experimental waste water.

る。高い酸素発生過電圧を持つ BDD 電極は廃水中の COD (Chemical Oxygen Demand: 化学的酸素要求量) 処理などへ

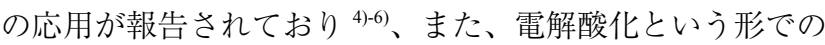
着色分子処理への応用も期待できたため、廃水の脱色処理 について検討した。

\section{実験方法}

まず始めに、BDD と従来多く用いられている他の機能性 電極 $\left(\mathrm{Pt}, \mathrm{IrO}_{2}\right)$ の脱色性能を比較した。試験廃水として、染 色廃水を想定して繊維製品や食品などの工業製品に広く使 用されている Acid Orange7 $\left(\mathrm{C}_{16} \mathrm{H}_{11} \mathrm{~N}_{2} \mathrm{NaO}_{4} \mathrm{~S}\right)$ の水溶液を用 い、濃度を $200 \mathrm{mg} / 1$ に調合した水溶液を準備した。また、 支持電解質として $\mathrm{Na}_{2} \mathrm{CO}_{3}$ と $\mathrm{NaHCO}_{3}$ をそれぞれ $1.0 \mathrm{~g}$ 添加 した。

陽極材料には、(1) BDD 電極、(2) $\mathrm{Ti}$ 基板上に $\mathrm{Pt}$ 層が被覆 された $\mathrm{Pt}$ 電極、(3) $\mathrm{Ti}$ 基板上に $\mathrm{IrO}_{2}$ を被覆した $\mathrm{IrO}_{2}$ 電極の 3 種類を使用した。BDD 電極は、幅 $50 \mathrm{~mm}$ 、長さ $100 \mathrm{~mm}$ 、 厚み $3 \mathrm{~mm}$ の $\mathrm{Si}$ 基板の両面に熱フィラメント CVD 法でボ ロンを添加しながら成膜したものであり、電気抵抗率は 1 $\times 10^{-1} \sim 10^{-2} \Omega \cdot \mathrm{cm}$ である。陰極には、サイズが $100 \mathrm{~mm} \times$ $50 \mathrm{~mm}$ の $\mathrm{Ti}$ 板を使用した。

電解実験は、Fig. 6 に示すように試験廃水を満たしたガ ラス製ビーカーに陽極と院極とを電極間距離が $10 \mathrm{~mm}$ にな るように設置して行った。

このような構成で $1.5 \mathrm{~A}$ 電流を流し、電解処理時間によ る試験廃水の脱色度合いを評価した。脱色度合いの評価方 法には、波長 $540 \mathrm{~nm}$ の光に対する試験廃水の吸光度を測 定することにより行った。

\section{実験結果と考察}

Fig. 7 に、陽極材質毎の電解処理時間による試験廃水の 吸光度変化を示す。Fig. 8 に、電解処理前の試験廃水と、 各電極材質で電解処理後の試験廃水の写真を示す。

Fig. 7 に示すように、陽極に $\mathrm{IrO}_{2}$ 電極や $\mathrm{Pt}$ 電極を用いた 場合、6 時間の電解処理により Acid Orange7 水溶液の吸光 


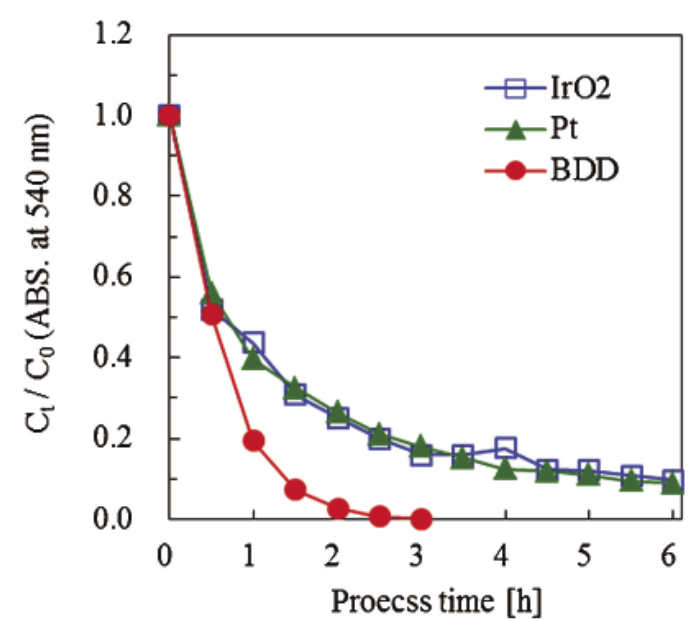

Fig. 7 Change of absorbance of Acid Orange7 solution.

度は $90 \%$ 以上減少した。しかし、Fig. 8 に示すように無色 には成らなかった。

一方、BDD 電極を用いた場合、約 3 時間の電解処理によ り吸光度は 0.001 になり、処理水は無色透明となり、他の 電極材質より非常に高い脱色性能を示した。

電解処理による脱色のメカニズムは、主に式 (1)に示す ように陽極にて、水分子が電子を失うことで生成されるヒ ドロキシラジカル $(\cdot \mathrm{OH})$ による着色分子の酸化である ${ }^{7)}$ 。

$\mathrm{H}_{2} \mathrm{O} \rightarrow \cdot \mathrm{OH}+\mathrm{e}^{-}+\mathrm{H}^{+}$

$\mathrm{BDD}$ 電極と $\mathrm{Pt}$ 電極・ $\mathrm{IrO}_{2}$ 電極の脱色性能が異なる主な理 由は、次の 2 つである。

(1)酸素発生過電圧の違い

BDD 電極は酸素発生過電圧が高いため、他の電極材料に 比べ水の電気分解以外の電解反応が進み易く、・OH の生 成効率が高い。

(2)電極材料の化学的安定性の違い

$\mathrm{Pt}$ 電極や $\mathrm{IrO}_{2}$ 電極では、電極材料自体の酸化に・OH が 消費されるため、着色分子の酸化に使用される· $\mathrm{OH}$ が減 少する。一方、BDD 電極は化学的に安定なため·OH と 反応せず、· $\mathrm{OH}$ は着色分子の酸化に使用される。

これらの違いが脱色性能の差に繋がっている ${ }^{8)}$ 。

\section{2) アンモニア性窒素・硝酸性窒素の処理}

次に、廃水中の污染物質の中でもアンモニア性、硝酸性 の 2 種の形態をとり、比較的困難である窒素系污染物質の 処理への BDD 電極の利用を検討した。

窒素は、人間の通常の生活廃水のみならず、農業、畜産業、 工業などの産業活動からも排出されており、主要な富栄養 化物質であり、湖沼の環境污染の観点から注目されている。 硝酸性窒素 $\left(\mathrm{NO}_{3}-\mathrm{N}\right)$ の、電解法による分解では、塩化物 イオンの存在下で㓌極に $\mathrm{Cu}$ 系電極を用いることで、硝酸

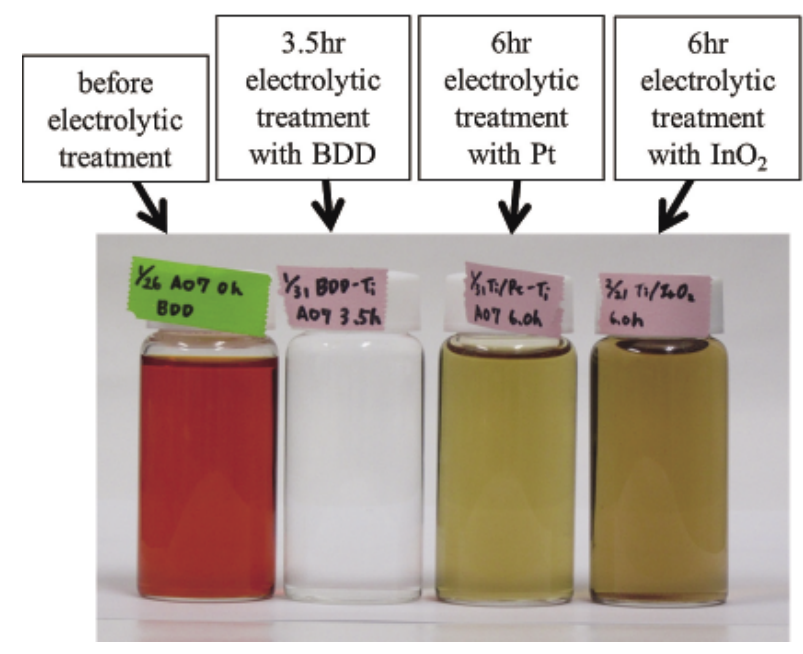

Fig. 8 Acid Orange7 solutions.

イオンをアンモニアに還元し、陽極にPt 系電極を用いる ことで、アンモニアを窒素に分解する方法が提案されてい る ${ }^{9)}$ 。

塩化物イオンの存在下で、陽極表面にて、アンモニア性 窒素 $\left(\mathrm{NH}_{4}-\mathrm{N}\right)$ が $\mathrm{N}_{2}$ ガスへ分解されるメカニズムを式 (2)〜 (7) に示す。

陽極での反応 : $2 \mathrm{Cl}^{-} \rightarrow \mathrm{Cl}_{2}+2 \mathrm{e}^{-}$

電極間バルクでの反応：

$\mathrm{Cl}_{2}+\mathrm{H}_{2} \mathrm{O} \rightarrow \mathrm{HOCl}+\mathrm{H}^{+}+\mathrm{Cl}^{-}$

$\mathrm{HOCl}+\mathrm{NH}_{4}^{+} \rightarrow \mathrm{NH}_{2} \mathrm{Cl}+\mathrm{H}_{2} \mathrm{O}+\mathrm{H}^{+}$

$\mathrm{HOCl}+\mathrm{NH}_{2} \mathrm{Cl} \rightarrow \mathrm{NHCl}_{2}+\mathrm{H}_{2} \mathrm{O}$

$\mathrm{NHCl}_{2}+\mathrm{H}_{2} \mathrm{O} \rightarrow \mathrm{NOH}+2 \mathrm{H}^{+}+2 \mathrm{Cl}^{-}$

$\mathrm{NHCl}_{2}+\mathrm{NOH} \rightarrow \mathrm{N}_{2}+\mathrm{HOCl}+\mathrm{H}^{+}+\mathrm{Cl}^{-}$

陽極で発生する塩素から生成する次亜塩素酸とアンモニ アイオンが反応し、“breakpoint reaction”と呼ばれる反応で $\mathrm{N}_{2}$ ガスへの分解が生じる。この反応は、電極表面で直接ア ンモニアを酸化する反応では無く、電極表面で生成した塩 素が関与する反応である。

一方で、塩化物イオンが存在しない場合は、次式 (8) で 示されるNO などの窒素酸化物の段階を経て窒素ガスに分 解される。これらの反応は、電極表面での反応である。こ の反応をまとめて、 $\mathrm{NH}_{4}-\mathrm{N}$ が $\mathrm{N}_{2}$ ガスへ分解される一般的 な電気化学反応として、式 (9) に示される反応が考えられ ている ${ }^{10)}$

しかしながら、酸化反応が強く、酸化が進み過ぎた場合 には、 $\mathrm{NO}_{3}-\mathrm{N}$ が生成されてしまい、窒素系污染物質の処理 としては、有効な方法ではない。 


$$
\begin{aligned}
& \mathrm{NH}_{3} \rightarrow \mathrm{NH}_{2} \mathrm{OH} \rightarrow \mathrm{NOH} \rightarrow \mathrm{NO} \rightarrow \mathrm{NO}_{2} \rightarrow \mathrm{NO}_{3}^{-} \\
& \downarrow \uparrow \\
& \mathrm{NH}_{4}^{+}(<\mathrm{pH} 7) \\
& \mathrm{N}_{2}
\end{aligned}
$$

$\mathrm{NH}_{3}+\mathrm{OH}^{-} \rightarrow(1 / 2) \mathrm{N}_{2}+3 \mathrm{H}_{2} \mathrm{O}+3 \mathrm{e}^{-}$

また、陰極表面にて、 $\mathrm{NO}_{3}-\mathrm{N} か ゙ \mathrm{NH}_{4}-\mathrm{N}$ 一還元されるメカ ニズムを、式 (10)〜 (11) に示す。

$$
\begin{aligned}
& \mathrm{NO}_{3}^{-}+\mathrm{H}_{2} \mathrm{O}+2 \mathrm{e}^{-} \rightleftarrows \mathrm{NO}_{2}^{-}+2 \mathrm{OH}^{-} \\
& \mathrm{NO}_{2}^{-}+5 \mathrm{H}_{2} \mathrm{O}+6 \mathrm{e}^{-} \rightleftarrows \mathrm{NH}_{3}+7 \mathrm{OH}^{-}
\end{aligned}
$$

このように $\mathrm{NO}_{3}-\mathrm{N} も \mathrm{NH}_{4}-\mathrm{N}$ に還元されることで、最終 的には、上述の $\mathrm{NH}_{4}-\mathrm{N}$ の分解と同じ反応で $\mathrm{N}_{2}$ ガスへ分解 される。

$\mathrm{BDD}$ 電極は、陽極・陰極のいずれの極でも使用可能とい う特徵をもっており、上記の酸化（式 (2)〜 (7)) ·還元（式 (10)〜 (11)）反応を BDD 電極だけで行える。両極で使える のは重要である。実際の廃水中にはカルシウムイオンやマ グネシウムイオンが溶解して扔り、それらのイオンが電解 処理中に陰極上に析出し、電解を阻害する。そのため、定 期的に陽極・陰極を反転させ析出物を除去する必要がある。 もし、院極の材質が陽極に使用できない物であれば、この 転極時に電極表面が酸化され劣化する。しかし、陽極・陰 極が BDD 電極のように両極で使用可能な物であれば、こ のような転極は全く問題なく行える。

今回、陽極・陰極それぞれにBDDを用いた場合の $\mathrm{NH}_{4}-\mathrm{N}$ 㧍よび $\mathrm{NO}_{3}-\mathrm{N}$ の分解性能に関する基礎的な検討の結 果を紹介する。

\section{2)-1 アンモニア性窒素の分解（陽極反応） \\ 実験方法}

まず、BDD 電極と機能性電極 DSE（Dimensionally Stable Electrode：寸法安定電極）の $\mathrm{NH}_{4}-\mathrm{N}$ の分解性能を比較した。 試験廃水として、 $\mathrm{NH}_{4}-\mathrm{N}$ 源としての炭酸水素アンモニウ ム $\left(\mathrm{NH}_{4} \mathrm{HCO}_{3}\right)$ と塩化ナトリウム $(\mathrm{NaCl})$ を混合した液を準 備した。溶液の濃度は、初期の $\mathrm{NH}_{4}-\mathrm{N}$ 濃度が $150 \mathrm{mg} / \mathrm{l}$ にな るように調合した。 $\mathrm{NaCl}$ の濃度は $700 \mathrm{mg} / 1$ となるように調 合した。

陽極材料には、電極材料に上る分解効果を比較する目的 で、(1) $\mathrm{BDD}$ 電極、(2) $\mathrm{Ti}$ 基板上に $\mathrm{IrO}_{2}$ と $\mathrm{RuO}_{2}$ 層を被覆し たDSEを使用した。

$\mathrm{BDD}$ の仕様は、上記の脱色試験で用いたものと同じであ

る。また、実験装置の構成は Fig. 6 と同様である。

このような構成に試験廃水を満たし、電極に直流電源を 用いて $1.5 \mathrm{~A} の$ 定電流を流した。

これらの条件で試験廃水を一定時間電解した後 $\mathrm{NH}_{4}-\mathrm{N}$ と $\mathrm{NO}_{3}-\mathrm{N}$ の濃度変化を調べた。

\section{実験結果と考察}

陽極材料による $\mathrm{NH}_{4}-\mathrm{N}$ の電解特性を調べたところ、Fig.

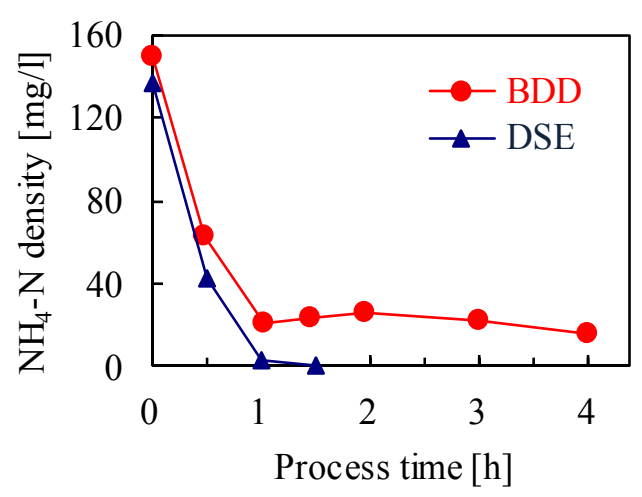

Fig. 9 Change of $\mathrm{NH}_{4}-\mathrm{N}$ density.

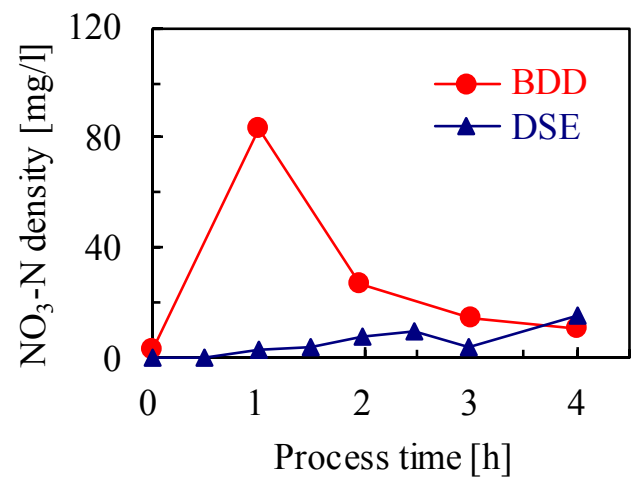

Fig. 10 Change of $\mathrm{NO}_{3}-\mathrm{N}$ density.

9 に示すように、反応時間が 1 時間までは 2 種類の電極と も $\mathrm{NH}_{4}-\mathrm{N}$ の濃度は急速に低下した。DSEを用いた場合、延 べ 1.5 時間の反応で $\mathrm{NH}_{4}-\mathrm{N}$ の濃度はほほ $0 \mathrm{mg} / \mathrm{l}$ となったが、 BDD を用いた場合、 1 時間の反応で $20 \mathrm{mg} / 1$ にまで減少し た以降は、ほとんど濃度の変化は無かった。

一方、Fig. 10 の $\mathrm{NO}_{3}-\mathrm{N}$ の濃度変化は、BDD を用いた場 合、一時的に増加が確認された。この原因は、BDDの酸 素発生過電圧が高いことに由来する高い酸化能力により、 $\mathrm{NH}_{4}-\mathrm{N}$ の酸化が進み過ぎ、 $\mathrm{NO}_{3}-\mathrm{N}$ が生成されたためである。 $\mathrm{NO}_{3}-\mathrm{N}$ 濃度は一旦増加した後、減少に転じているが、この メカニズムは不明である。

よって、 $\mathrm{NH}_{4}-\mathrm{N}$ の分解に扮いては、BDD 電極は、DSE とは異なり、完全に $\mathrm{NH}_{4}-\mathrm{N}$ は分解されず、DSE の方が処理 能力が高い結果となった。

\section{2)-2 硝酸性窒素の分解（陰極反応） 実験方法}

BDD 電極を陰極に用いた場合の $\mathrm{NO}_{3}$ - $\mathrm{N}$ の分解性能を評 価した。試験廃水の $\mathrm{NO}_{3}-\mathrm{N}$ 源として硝酸ナトリウム $\left(\mathrm{NaNO}_{3}\right)$ を用いた。溶液の濃度は $\mathrm{NO}_{3}-\mathrm{N}$ 濃度が $50 \mathrm{mg} / 1$ となるよう 


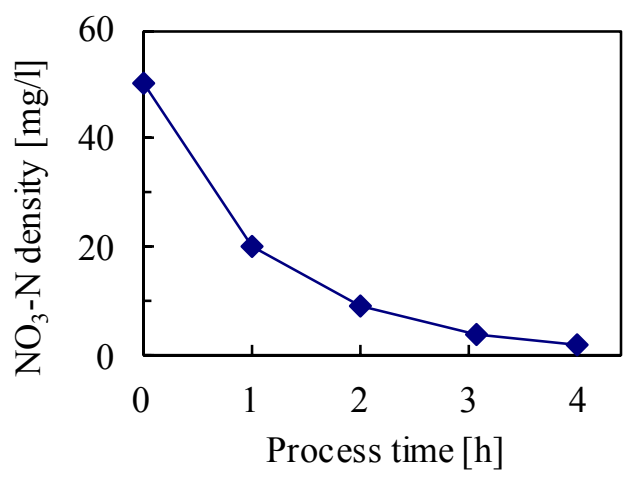

Fig. 11 Change of $\mathrm{NO}_{3}-\mathrm{N}$ density.

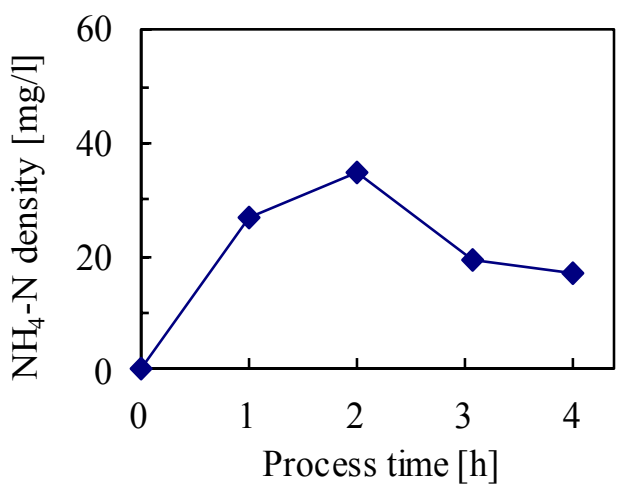

Fig. 12 Change of $\mathrm{NH}_{4}-\mathrm{N}$ density.

に調合した。塩化物 $(\mathrm{NaCl})$ の濃度は $500 \mathrm{mg} / 1$ とした。

陽極材料には、 $\mathrm{Ti}$ 基板上に $\mathrm{IrO}_{2}$ を被覆した DSE を使用 し、陰極材料には、先の実験と同様の BDD 電極を使用した。 実験装置の構成は Fig. 6 と同様である。

このような構成に試験廃水を満たし、電極に直流電源を 用いて 3 A の定電流を流した。

これらの条件で試験廃水を一定時間電解した後の $\mathrm{NO}_{3}-\mathrm{N}$ と $\mathrm{NH}_{4}-\mathrm{N}$ の濃度変化を調べた。

\section{実験結果と考察}

Fig. 11 に示すように、反応時間が長くなるほど、 $\mathrm{NO}_{3}-\mathrm{N}$ の濃度は減少した。逆に Fig. 12 に示す $\mathrm{NH}_{4}-\mathrm{N}$ の濃度は一 旦増加した。 $\mathrm{NH}_{4}-\mathrm{N}$ は、BDD 電極により $\mathrm{NO}_{3}-\mathrm{N}$ が還元さ れて生成したものである。

先の $\mathrm{NH}_{4}-\mathrm{N}$ の分解の実験において、陽極として用いた DSE は高い $\mathrm{NH}_{4}-\mathrm{N}$ の分解能力を示したが、今回の実験にお いては、BDD 陰極による $\mathrm{NH}_{4}-\mathrm{N}$ の生成速度に分解が追い 付かず $\mathrm{NH}_{4}-\mathrm{N}$ は増加した。

\section{アンモニア性窒素・硝酸性窒素の分解のまとめ}

BDD を陽極に用いた場合、アンモニアの分解を確認し、 BDD を陰極に用いた場合、硝酸がアンモニアに還元される
Table 2 Recovery methods of copper.

\begin{tabular}{|c|l|l|l|}
\hline Method & Scrap material & \multicolumn{1}{|c|}{ Process } & \multicolumn{1}{c|}{ Issues } \\
\hline Dry & $\begin{array}{l}\text { Crushing } \\
\rightarrow \text { Gravity concentration } \\
\text { line }\end{array}$ & $\begin{array}{l}\text { Heavy environmental load } \\
\mathrm{CO}_{2} \text { emission during the } \\
\text { resin } \\
\rightarrow \text { Recovering as copper } \\
\text { oxides }\end{array}$ & $\begin{array}{l}\text { combustion process } \\
\text { is large. } \\
\cdot \text { Reduction treatment for } \\
\text { copper oxides is needed. }\end{array}$ \\
\hline Wet & $\begin{array}{l}\text { Printed circuit } \\
\text { board of } \mathrm{PC} \text { or } \\
\text { consumer } \\
\text { electronics }\end{array}$ & $\begin{array}{l}\text { Eluting Cu with } \mathrm{SO}_{4} \\
\text { or } \mathrm{HCl} \text { etc } \\
\rightarrow \text { Recovering Cu with } \\
\text { electrowinning }\end{array}$ & $\begin{array}{l}\text { Heavy environmental load } \\
\cdot \text { A lot of chemicals are } \\
\text { used. } \\
\text { - Electricity consumption } \\
\text { used at the electrowinning } \\
\text { process is large. }\end{array}$ \\
\hline
\end{tabular}

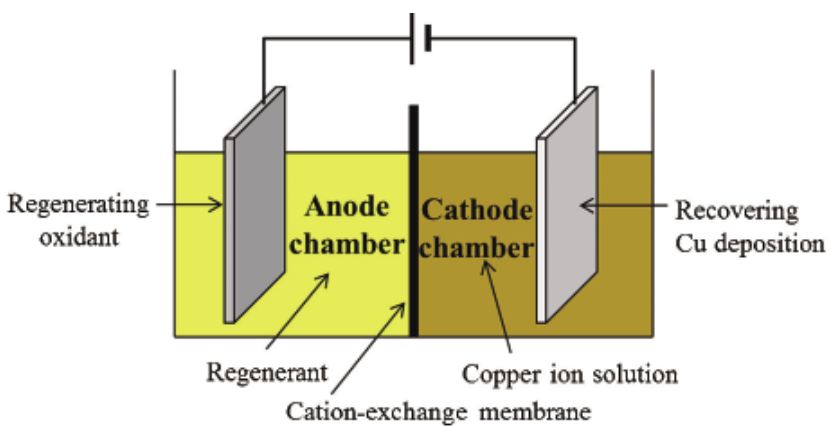

Fig. 13 Recovery system of copper using BDD electrode.

ことを確認した。

この結果から、両極とも BDDを用いた構成で、 $\mathrm{NH}_{4} \mathrm{-N}$ と $\mathrm{NO}_{3}$-N の両方の分解が可能であり、COD の分解や陰極 上の付着物除去を目的とした転極を考えると、BDDを両極 に用いることが実用上有効であることがわかる。

\section{2 銅のリサイクル}

BDD 電極の高い酸化力を用いて、硫酸や炭酸から過硫酸 や過炭酸などの強い酸化剂を生成する応用が幾つか報告さ れている ${ }^{7), 11}$ 。

ここでは、このような応用を銅のリサイクルに利用した 事例を紹介する。

銅は、需要は大きいが埋蔵量が決して多く無い金属であ る。従って、銅を含有した銅スクラップから銅を回収して 再利用することは、資源保護の立場から重要である。

従来の銅の回収方法としては、Table 2 に示すものが代 表的である。しかし、これらの方法は何れも、純度が低い、 環境負荷が大きい等の課題がある。

BDD 電極は、環境への負荷を大きくすることなく、高純 度に銅の回収が期待できるため、以下に実験結果を示す。

BDD 電極を用いた銅の回収方法

実験装置の構成

Fig. 13 に銅の回収に使用する電解槽の構成を示す。陽イ 
ボロンドープによるダイヤモンドの電気化学的特性の向上とその応用（吉田・小林・中島）

Table 3 Process of copper recovery system using BDD electrode.

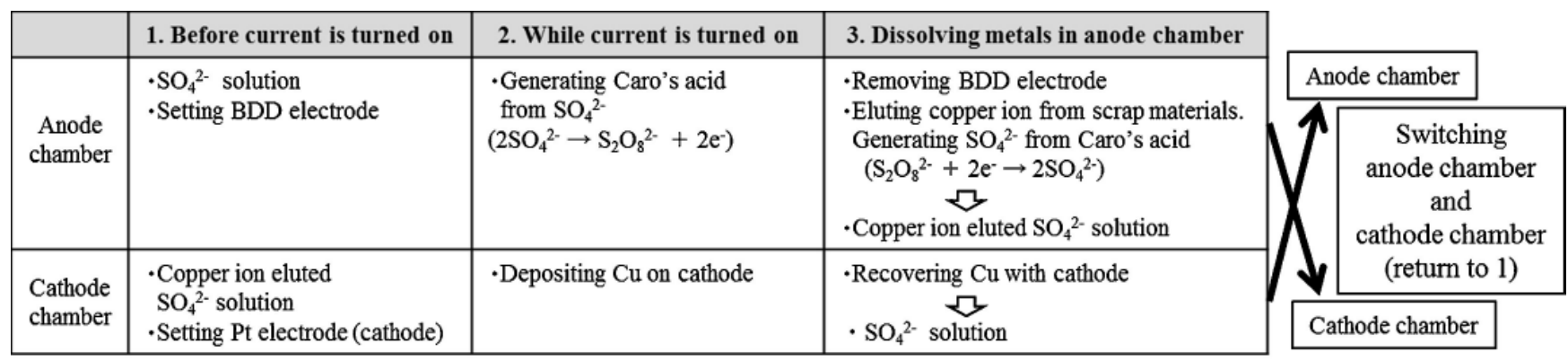

オン交換膜により、陽極を備えた陽極室と、陰極を備えた 陰極室とに仕切られている。

陽極には BDD 電極、陰極には Ti に Pt をコートした Pt 電極を用いた。

\section{銅の回収プロセス}

先ず銅線の粉砕物をポリプロピレン製の不織布でできた 袋に詰めた物を用意した。

次に、上記の金属含有物の粉砕物が詰まった袋を $6 \mathrm{~N} の$ 硫酸 $1 \mathrm{~L}$ に $60 \mathrm{~g}$ の過硫酸アンモニウムを加えて作成した溶 液に浸し、銅イオンを含む溶液を用意した。このとき、式 (12) に示すように過硫酸イオンは還元され硫酸イオンとなる。

$\mathrm{S}_{2} \mathrm{O}_{8}{ }^{2-}+2 \mathrm{e}^{-} \rightarrow 2 \mathrm{SO}_{4}{ }^{2-}$

Fig. 13 の陰極室に上記で用意した銅イオンを含む溶液を入 れ、更に陽極室には、6 $\mathrm{N}$ の硫酸 $1 \mathrm{~L} に 60 \mathrm{~g}$ の硫酸アンモ ニウムを溶かした溶液を入れた。

膜を介して陽極と陰極を約 $10 \mathrm{~cm}$ 離して対向させ両極間 に $10 \mathrm{~V}$ の電圧を印加して、10 分間通電処理した。

その結果、㓌極には純度 $99.99 \%$ 銅が析出し、一方、陽 極室では硫酸イオンが酸化されて濃度が $80 \mathrm{~g} / \mathrm{L}$ の過硫酸ア ンモニウム溶液が生成した。過硫酸イオンは式 (13) で示さ れる陽極反応で生成される。

$2 \mathrm{SO}_{4}{ }^{2-} \rightarrow \mathrm{S}_{2} \mathrm{O}_{8}{ }^{2-}+2 \mathrm{e}^{-}$

続いて、陽極および陰極をそれぞれの室から取り出し、 上記と同様に準備した金属含有の粉砕物が詰められた袋を 陽極室として用いていた室中の溶液に浸し、銅イオンを含 む溶液を作製した。そして、当該溶液中に新たに用意した $\mathrm{Pt}$ 製の陰極を設置し、もう一方の還元された状態の酸化物 を多く含む溶液中に上記の BDD 電極を設置し、両極間に $10 \mathrm{~V}$ の電圧を印加し、10 分間通電処理した。

1 回目の通電処理と同様に、陰極の表面には純度が 99.99 $\%$ の銅が析出し、陽極室中の溶液は酸化剂が再生して濃度 が $80 \mathrm{~g} / \mathrm{L}$ の過硫酸アンモニウム溶液となっていた。

上記のサイクルをまとめると、陽極室・陰極室において

Table 3 に示す反応が起きている。通電の度に陽極室にて
過硫酸イオンが再生するため、薬液（過硫酸アンモニウム 等）を追加することなく、繰り返し金属含有粉砕物を溶か すことが可能である。

また、同様の操作を繰り返し行ったところ、100 サイク ル後においても処理液を交換することなく、連続して利用 できることを確認した。

\section{他材質電極との比較}

BDD 電極の代わりにPt 製の陽極を用いた以外は、Fig 13 と同様にして、電解槽のセッティングを行った。両極 間に $10 \mathrm{~V}$ の電圧を印加し、10 分間通電処理をしたところ、 㓌極表面に純度 $99.99 \% の$ 銅が析出したが、陽極室におい ては、過硫酸イオンは生成されておらず、先の実験と同様 に操作を繰り返したところ、15～20 サイクル目で銅を溶 解させることができなくなった。

$\mathrm{BDD}$ 電極と $\mathrm{Pt}$ 電極の酸化力（酸素発生過電圧）の差が 過硫酸イオンの生成効率の違いに繋がり上記のような結果 となった。

\section{銅リサイクルのまとめ}

BDD 電極を陽極に用いた系にて、電析で銅を回収する事 例を示した。この系において、陽極・陰極間に通電時、陰 極に銅が析出すると同時に、BDD 電極の高い酸化力によ り硫酸イオンが酸化され過硫酸イオンが生成した。このよ うに銅の電析を行いながら過硫酸イオンの再生ができるた め、新たに過硫酸イオンを追加すること無く、繰り返し銅 廃材から銅を回収することができ、従来の銅回収方法に比 べ環境負荷を大幅に低減できる。

今回は、銅回収の事例を示したが、Fig. 13 の両極間の電 圧を制御すれば、溶液中の金属イオンの中からイオン化傾 向が小さい元素から順に分けて陰極に析出させることも可 能である。

\section{4. 結 言}

BDD 電極の優れた電気化学的特性を利用した廃水中の 污染物質の処理や、過酸化物生成による金属回収の例を示 した。これらはBDD 電極の応用のほんの一例に過ぎず、 Table 4 のように、BDD 電極に期待される応用分野は微量 
Table 4 Applications of BDD electrode.

\begin{tabular}{|l|l|}
\hline \multicolumn{1}{|c|}{ Field } & \multicolumn{1}{c|}{ Applications } \\
\hline $\begin{array}{l}\text { Waste water } \\
\text { treatment }\end{array}$ & $\begin{array}{l}\text { Removing COD or nitrogen } \\
\text { pollutant. Decolorization. } \\
\text { Sterilizing. Detoxifying } \\
\text { residual agricultural chemicals. }\end{array}$ \\
\hline Sensing & $\begin{array}{l}\text { Monitoring heavy metals, } \\
\text { residual Cl density, poisonous } \\
\text { gas, bio-related materials. }\end{array}$ \\
\hline $\begin{array}{l}\text { Electrolytic } \\
\text { synthesis }\end{array}$ & $\begin{array}{l}\text { Synthesis of peroxide, ozone, } \\
\text { organic matter, Fluorine gas. }\end{array}$ \\
\hline $\begin{array}{l}\text { Resource } \\
\text { recovery }\end{array}$ & $\begin{array}{l}\text { Recovering metals from scrap } \\
\text { materials. Reusing plating } \\
\text { waste water. Collecting Mg } \\
\text { from sea water. Reprocessing } \\
\text { nuclear fuel. }\end{array}$ \\
\hline
\end{tabular}

物質検出用のセンサから、 $\mathrm{CO}_{2}$ から有機物の合成 ${ }^{12)}$ 、海水 から有価資源の回収 ${ }^{13)}$ に至るまで幅広い。それらの研究開 発は年々盛んになっており、実用的な段階にまで進んで来 たものもある。

しかし、このような BDD 電極にもまだ課題はある。特に、 大面積 BDD 電極の製造技術確立と製造コスト削減は重要 である。サイズが $50 \mathrm{~cm} \times 100 \mathrm{~cm}$ の BDD 電極の製造実績 が報告されているが ${ }^{14)}$ 、量産性がそしく価格が課題である。 今後、BDD 電極が広く利用されるようになるには、生産技 術面でのブレイクスルーが特に必要である。

\section{謝 辞}

BDD 電極を用いた脱色処理実験と窒素性污染物質処理実 験のデータを御提供頂いた神戸大学農学部准教授の井原一 高様に感謝致します。

\section{引用文献}

1) 栄長泰明、近藤剛史、錦義則、初代善夫：NEW DIAMOND., 27-1 (2011) 31

2) Y. Einaga: J. Appl. Electrochem., 40 (2010) 1807

3) N. Katsuki, E. Takahashi, M. Toyoda, T. Kurosu, M. Iida, S. Wakita, Y. Nishiki and T. Shimamune, J. Electrochem. Soc., 145-7 (1998) 2358

4) X. Chen, G. Chen, F. Gao and P. L. Yue: Environment. Sci. Technol., 37-21 (2003) 5021

5) M. A. Rodrigo, P. A. Michaud, I, Duo, M, Panizza, G. Cerisola and Ch, Comninellis: J. Electrochem. Soc., 148-5 (2001) D60

6) A. Kraft, M. Stadelmann and M. Blaschke: J. Hazardous Mater., B, 103 (2003) 247

7) 芹川正浩、佐々木賢一、千田祐司：エバラ時報、223 (2009) 11

8) Comninellis, C: Electrochimica Acta., 39 (1994) 1857

9) 広瀬潤、広直樹、近藤文剛、河内基樹、黒川喜寛：SANYO Tech. Rev., 35-2 (2003) 15

10) K. W. Kim, Y. J. Kim, I. T. Kim, G. I. Park and E.H. Lee: Electrochim. Acta., 50 (2005) 4356

11) 速水直哉、田家真紀子：東芝レビュー、64-5 (2009) 38

12) K. Nakata, T. Ozaki, C. Terashima, A. Fujishima and Y. Einaga: Angew. Chem. Int. Ed., 53 (2014) 871

13) S. Ikeda and S. Tao: Bull. Soc. Sea Water Sci,, Jpn., 67-3 (2013) 141

14) M. Fryda, Th. Matthée, S. Mulcahy, M. Höfer, L. Schäfer and I. Tröster: The electrochemical Society Interface., Spring, (2003) 40 